sciendo Порівняльна професійна педагогіка 9(2)/2019 Comparative Professional Pedagogy 9(2)/2019

DOI: $10.2478 /$ rpp-2019-0013

$\mathrm{PhD}$ in Pedagogy, Associate Professor, OLENA TERENKO

A. S. Makarenko Sumy State Pedagogical University Address: 87 Romenska St., Sumy, 40000, Ukraine E-mail: eterenko@ukr.net

\title{
DIVERSIFICATION OF STRUCTURAL AND CONTENT PECULIARITIES OF NON-FORMAL ADULT EDUCATION IN THE USA AND CANADA
}

\begin{abstract}
Types of non-formal adult education in the USA and Canada are singled out. Nonformal adult education in the United States and Canada is subdivided into basic adult education, education for professional development, education for personal development, specialized adult education, education for the development of civil society (constituents of which are education for peace, citizenship and democracy; education for protection of environment; multicultural education). The purpose and main assignments of adult education for professional development are systematized. The purpose is professional development, meeting the needs of personal development, self-actualization and self-realization in professional life. Its main tasks are: formation of positive attitude to professional work and motivation for professional growth; enriching social and professional competence; development of adequate professional conduct. Types of educational establishments for adults are systematized. University colleges, community colleges, colleges of general and vocational education, colleges of applied arts are an alternative to university education of adults in Canada and the USA. Specifics of programs in American and Canadian colleges is analyzed. Colleges and institutes introduce programs aimed at solving social problems, taking into account labor market demands. They offer training programs for development of applied skills in business, art, technology, agriculture, social and educational fields, medicine. A special place in non-formal education for professional development is given to education for the labor market, which is aimed at obtaining specific professional competencies that are necessary at labor market. Adults are involved in professional programs, trainings, courses, seminars, internships.
\end{abstract}

Keywords: non-formal adult education, USA, Canada, apprenticeship, college, university, structural peculiarities, content peculiarities.

\footnotetext{
АНОТАЦІЯ

Виокремлено види неформальної освіти дорослих у США $і$ Канаді. Неформальна освіта дорослих у США і Канаді включає в себе базову освіту дорослих, освіту для професійного розвитку, освіту для особистісного розвитку, спеиіалізовану освіту дорослих, освіту для розвитку громадянського суспільства (складниками якої є освіта для миру, громадянства та демократії, освіта для захисту навколишнього середовища, полікультурна освіта). Систематизовано мету та ключові завдання неформальної освіти дорослих для професійного розвитку. Метою неформальної освіти дорослих є задоволення потреб особистості у розвитку, саморозвитку, самоактуалізаиї i реалізації себе у професійному житті. Основними ї̈ завданнями є: формування позитивної установки на професійну діяльність і мотиваиії професійного зростання; збагачення сочіально-професійної і спеціальної компетентності дорослої людини;
} 
sciendo Порівняльна професійна педагогіка 9(2)/2019 Comparative Professional Pedagogy 9(2)/2019

формування нових напрямків професійного розвитку дорослої людини і адекватних їм схем професійної поведінки. Систематизовано види навчальних закладів для дорослих учнів. Альтернативою університетської освіти дорослих у Канаді $i$ США $\epsilon$ університетські коледжі, громадські коледжі, коледжі загальної та професійної освіти, коледжі прикладних мистеитв та технологї̈, інститути технологї та посиленого навчання. Проаналізовано спечифіку програм у американських і канадських коледжах. Коледжі та інститути досить гнучко, відповідно до запитів ринку прачі вводять програми, спрямовані на розв'язання суспільних та сочіальних проблем. Вони пропонують програми професійної підготовки для розвитку прикладних навичок у бізнесі, мистеитві, технології, сільському господарстві, соиіальних та освітніх сферах, медицині. Особливо місие у неформальній освіті для професійного розвитку займає освіта для ринку праці, яка спрямована на отримання певних професійних компетентностей, які $\epsilon$ актуальними на ринку прачі. Дорослі залучаються до професійних програм, тренінгів, курсів, семінарів, стажувань.

Ключові слова: неформальна освіта дорослих, США, Канада, учнівство, коледж, університет, структурні особливості, змістові особливості.

\section{INTRODUCTION}

Socio-economic transformations in Ukraine influence innovative processes in education. Rapid increase of scientific knowledge volume, changes in technologies and industry organization help to transform education into life-long one. At the beginning of the XXI century higher educational institutions of the USA and Canada began to consider adult education as one of the priorities of their functioning. High level of adult education is provided by powerful scientific and methodological potential, modern technical facilities, highly qualified teaching staff, research and theoretical development in this area and significant practical experience of adults.

\section{THE AIM OF THE STUDY}

The aim of the study is to explore structural and content peculiarities of nonformal adult education in the USA and Canada.

\section{THEORETICAL FRAMEWORK AND RESEARCH METHODS}

The problem of adult education was researched by such Ukrainian scientists as N. Bidyuk (2009), O. Ohiienko (2014). Different aspects of adult education in the USA and Canada were analyzed by foreign scientists: philosophical basics of adult education (Bergevin, 2014; Bogard, 2012), training of educators for adults (Brookfield, 2018), procedural aspects of teaching (Kruidenier, 2010; Langenbach, 2014; Merriam, 2013). To fulfill the aim of our research we will apply the following methods: analysis, synthesis, induction, deduction, analogy, comparative historical method, genetic method, problemchronological method.

\section{RESULTS}

Analysis of scientific sources allows us to distinguish main types of non-formal adult education in the United States and Canada, taking into account specific context (school, work, community, family, self-development), focus of educational activities, general aims, content and direction of their implementation:

- basic adult education, which plays important role in the fight against illiteracy. Its dominant feature is compensatory, which updates compensation shortfall of formal education and received remedial education; 
sciendo Порівняльна професійна педагогіка 9(2)/2019 Comparative Professional Pedagogy 9(2)/2019

- education for professional development, which presupposes broadening and mastering of certain competences, corporate education, training in the workplace. Its dominant feature is adaptive, which provides adult adaptation to changes in the labor market;

- education for personal development, provides functional mastery and critical literacy, and aims at meeting development needs, spiritual needs and interests of adult;

- specialized adult education, which includes education, targeted at enrichment of knowledge and skills that are needed for adequate performance of social roles (education for parents, education of women, education of people of the third age, education for the integration into society of people with certain disabilities), focuses on vulnerable populations (minorities, immigrants, people with disabilities and others;

- education for the development of civil society, constituents of which are education for peace, citizenship and democracy; education for protection of environment; multicultural education.

The purpose of education for professional development meeting the needs of personal development, self-actualization and self-realization in professional life. Its main tasks are: formation of positive attitudes in professional work and motivation for professional growth; enriching social and professional competence; development of adequate professional conduct (Bergevin, 2014).

Canadian and American universities have experience of programs for adults inclusion in their own traditional system.

The programs of lifelong university education reflect peculiarities of American and Canadian economy, because significant number of educational establishments train specialists and improve professional skills of workers in agriculture, fishery, forestry, metallurgy, chemical and mining industry. Universities provide an opportunity to improve skills and get training in the following areas: agricultural science, business and management, education, engineering and applied science, medicine, mathematics and computer science, physics, social and human science, transport and communication (Langenbach, 2014).

University colleges, community colleges, colleges of general and vocational education, colleges of applied art are an alternative to adult university education in Canada and the USA.

Canadian and American system of public colleges was formed only in 1960. Unlike universities, which have come a long way of evolution, a system of colleges formation was initiated by the government, taking into account necessity of socioeconomic development of the United States and Canada, because it was thought that economic growth is possible only due to significant investment in the development of technical skills of population (Bogard, 2012).

Vast majority of colleges in the USA and Canada provide vocational training and are considered as steps for admission to universities, though some of them implement programs for bachelor degree obtaining, and receive significant government support.

Colleges and institutes introduced programs aimed at solving social problems rather flexibly, taking into account labor market demand. They offer programs for the development of applied skills in business, art, technology, agriculture, social and educational fields, medicine.

A special place in non-formal education for professional development is given to education for the labor market, which is aimed at obtaining specific professional competencies that are necessary at labor market. Adults are involved in professional programs, trainings, courses, seminars, internship.

Nunavut Arctic college offers a significant range of educational programs aimed at training mid-level specialists needed in the district. An example of such educational 
program serves training of students for timber industry (carpentry pre-employment). The duration is 1 year. On completion of program, students receive a certificate. The second part of program (carpentry apprenticeship) provides practically oriented training of specialists in the field of construction, erection and reparation of wooden and concrete structures. The program offers acquisition of skills that are necessary for installation of doors, windows, staircases reading blueprints and calculating material. To be enrolled for the program an applicant must reside on the territory of Nunavut, be physically prepared for this type of activity and needs to find an employer who agrees to employ him after graduation. The program lasts four years, during which every seven weeks theoretical course is conducted (the theory of timber production, sale of timber industry goods). After successful completion of program students receive a license with the right for employment in the wood industry (journeyman carpentry ticket) (Brocket, 2014). In addition, college enables Aboriginal people to get the skills in development of mineral deposits (mine training); social assistance of Aboriginal health monitoring, disease prevention (community health); food industry (culinary art); early childhood education (early childhood education); business travel (guide training); housing (housing maintainer), etc.

Federal programs and initiatives help adults become competitive in the labor market: program for fired workers (dislocated worker program), national program for vocational training of representatives of rural areas (national farmworker jobs program), program of assistance in employment (employment and training assistance), project for homeless veterans reintegration (homeless veterans reintegration project), program for employment of former soldiers (local veterans employment representative program), employment and training program for the indigenous inhabitants of America (native American employment and training program), program of employment of older people (senior community service employment program) (Langenbach, 2014).

Study at work and corporate training is an important part of non-formal education for professional development of adults. So, two out of three workers feel that they can learn much more at work than in classroom. Therefore, almost $58 \%$ of informal learning takes place in companies (Bogard, 2012). Training at workplace includes: experience that is gained in the process of work and apprenticeship.

A special place in the system of adult education in Canada unlike in the USA is given to apprenticeship - vocational training for adults, who wish to improve their skills by combining learning at workplace and at educational establishment. Adult student training period, according to the apprenticeship program, lasts from 2 to 5 years depending on the subject and on how quickly the student can accumulate credits required for the number of working hours. On average, student spends $85 \%$ of time at company and only $15 \%$ attending educational institutions. To be enrolled in apprenticeship courses a candidate must formally apply for a job and have a journeyman status. On completion of program, he receives a certificate of apprenticeship and if it is necessary passes an exam for getting a certificate (Bogard, 2012).

Adults, who wish to increase the level of professional qualification, can take part in Co-Op Diploma Apprenticeship Program, which combines study in college and vocational training, which is proved by certificate of qualification. Studying in college, participants of this program get standard training and practical course in chosen specialty. The program includes business training and entrepreneurship, aimed at developing skills that are necessary for creating and managing ones own business. In addition, participants have practical training in workplace, after which the official document is given if student passes exam that meets professional requirements. 
sciendo Порівняльна професійна педагогіка 9(2)/2019 Comparative Professional Pedagogy 9(2)/2019

Non-formal adult education for personal development is aimed at selfdetermination of adults and developing family relations, communication, intellectual, moral, artistic, physical, environmental, economic culture. Culture is based on life of selfconscious adult who is able to make decisions, identify himself, take responsibility for actions in different situations, take his own way in cultural, professional, social, interpersonal and other relationships with people.

It was found that human society is an important area of self-determination and integrative product of human activity. Therefore, non-formal adult education for personal development focuses on enriching cognitive abilities and acquireing new ideas about world, offering adults a large number of courses, workshops, seminars, lectures, debates on various subjects and directions in accordance with their interests and needs. However, nonformal adult education for personal development is aimed at developing understanding of person's strengthses and weaknesses.

The structure of non-formal adult education in the USA and Canada is characterized by rapid development, for it is determined by society, needs and interests of adults, economy and society and fast changes taking place in society. Therefore, non-formal adult education in the USA and Canada has ability to cover different groups of adults, that allows to distinguish its structure and skills of adults that are necessary for adequate performance of social roles (education of parents, education of women, education of people of the third age, education for the integration into society of people with certain disabilities), it also focuses on vulnerable population (minorities, immigrants, people with special needs).

Saskatchewan Indian federated college provides aboriginal adult learning, combining traditional Indian and Western techniques. The college offers a program of Aboriginal art. College policy focuses attention on the study of tribal culture, not taken apart from life in Aboriginal realities; usage of holistic, integrated, comprehensive approach to learning rather than abstract fragmented approaches that are typical for traditional Western pedagogy (Bergevin, 2014).

The implementation of such training programs for indigenous people in Canada has many advantages: solution of problem of equal access to Aboriginal education; territorial government overcomes the problem of national personnel in the service and production; removement of various obstacles for those who wish to continue education, particularly overcome one of the major barriers - financial, since there is no need to pay for accommodation, transportation, food; indigenous population of Canada supports and develops communication skills in their own national environment.

\section{CONCLUSIONS}

The main types of non-formal adult education in the United States and Canada are basic adult education, education for professional development, education for personal development, specialized adult education, education for the development of civil society (constituents of which are education for peace, citizenship and democracy; education for protection of environment; multicultural education). The purpose of non-formal adult education for professional development is meeting the needs of personal development, selfactualization and self-realization in professional life. Its main tasks are: formation of positive attitude in professional work and motivation for professional growth; enriching social and professional competence; development of adequate professional conduct. Vast majority of colleges in the USA and Canada provide vocational training and are considered as steps for admission to universities, though some of them implement programs for bachelor degree obtaining, and receive significant government support. Colleges and institutes introduced programs aimed at solving social problems, taking into account labor market demand. 


\section{REFERENCES}

1. American Association for Adult and Continuing Education. (2019). Retrieved from http://www.aaace.org/.

2. Bergevin, P. (2014). Philosophy for adult education. New York, NY: Seabury.

3. Bidyuk, N. (2009). Profesiine navchannia bezrobitnykh u SSHA: teoriia $i$ praktyka. Khmelnytskyi: KhmTsNTEI.

4. Bogard, G. (2012). For a socialising type of adult education. Strasbourg: Council for Cultural Cooperation.

5. Brockett, R. (2014). Self-direction in adult learning: perspectives on theory, research, and practice. London: Routledge.

6. Brookfield, S. (2018). Training Educators of Adults: The Theory and Practice of Graduate Adult. London: Routledge.

7. Kruidenier, J. (2010). Adult education literacy instruction: a review of the research. Washington, DC: National Institute for Literacy.

8. Langenbach, M. (2014). Curriculum models in adult education. New York, NY: Krieger Pub Co.

9. Merriam, S. (2013). Adult learning: linking theory and practice. San Francisco, CA: Jossey-Bass.

10. Ohiienko, O. (2014). Andrahohichna model navchannia: amerykanskyi kontekst. Kyiv: Tsentr uchbovoi literatury. 